Article

\title{
Effects of High Hydrostatic Pressure Pretreatment on the Functional and Structural Properties of Rice Bran Protein Hydrolysates
}

\author{
Shirang Wang ${ }^{1}$, Tengyu Wang ${ }^{2}$, Yue Sun ${ }^{1}$, Yingju Cui ${ }^{1}$, Guoping Yu ${ }^{1, *}$ and Lianzhou Jiang ${ }^{1}$ \\ 1 College of Food Science, Northeast Agricultural University, Harbin 150030, China; \\ wangshirang2017@126.com (S.W.); 15533765253@163.com (Y.S.); cyingjy@163.com (Y.C.); \\ jlzname@163.com (L.J.) \\ 2 School of Grain Engineering, Heilongjiang Communications Polytechnic, Harbin 150025, China; \\ wangtengyu2017@126.com \\ * Correspondence: yuguoping@neau.edu.cn
}

check for updates

Citation: Wang, S.; Wang, T.; Sun, Y.; Cui, Y.; Yu, G.; Jiang, L. Effects of High Hydrostatic Pressure Pretreatment on the Functional and Structural Properties of Rice Bran

Protein Hydrolysates. Foods 2022, 11, 29. https://doi.org/10.3390/ foods11010029

Academic Editor:

Francisco Artés-Hernández

Received: 13 November 2021

Accepted: 21 December 2021

Published: 23 December 2021

Publisher's Note: MDPI stays neutral with regard to jurisdictional claims in published maps and institutional affiliations.

Copyright: (C) 2021 by the authors. Licensee MDPI, Basel, Switzerland. This article is an open access article distributed under the terms and conditions of the Creative Commons Attribution (CC BY) license (https:// creativecommons.org/licenses/by/ $4.0 /)$

\begin{abstract}
Rice bran protein (RBP) hydrolysis was conducted after high hydrostatic pressure (HHP) pretreatment. The structural and functional properties of HHP-pretreated rice bran protein hydrolysates (RBPH) were investigated. HHP pretreatments were conducted at 100, 200, and $300 \mathrm{MPa}$; then, enzymatic hydrolysis at atmospheric pressure was performed using trypsin. An RBPH sample that had not been pretreated by HHP was used as a control. Free sulfhydryl (SH) content, SDS-PAGE profiles, high-performance size exclusion chromatography (HPSEC), Fourier transform infrared (FTIR) spectrum, scanning electron microscopy (SEM), intrinsic fluorescence spectrum, solubility, and emulsifying and foaming properties were evaluated. Changes in particle size and $\zeta$-potential were monitored. Compared with the control, the results of solubility, the emulsifying activity index (EAI) and the emulsifying stability index (ESI) increased significantly $(p<0.05)$ at $200 \mathrm{MPa}$. The content of free SH increased significantly $(p<0.05)$ at $100 \mathrm{MPa}$. FTIR spectrum and fluorescence analysis confirmed the changes in the secondary and tertiary structures. The experimental results indicated that the structural and functional properties of HHP-pretreated RBPH improved.
\end{abstract}

Keywords: high hydrostatic pressure; trypsin; hydrolysis; rice bran protein hydrolysate; solubility; emulsifying property; protein structure

\section{Introduction}

Rice bran is a low-priced, underutilized major by-product of rice processing [1]. Rice bran contains protein (12-16\%), fat (15-20\%), and fiber (23-28\%) [2]. It also contains many other nutrients, such as phytosterols, vitamins, and antioxidants [3]. Rice bran protein (RBP), which contains lysine (3-4\%), is a high-quality resource of protein for the food processing industry, and the content of lysine in RBP is much higher than that of proteins from many other cereal brans or legumes [4,5]. The protein efficiency ratio of RBP (1.6-1.9) is comparable with that of casein (2.5) [5]. RBP is used in the modern infant food industry also because it is a low-allergy protein [6,7]. The demand for cheap and high-quality plant proteins for applications in food processing, especially for infant formula, is increasing, and scholars have been searching for this kind of protein for a few years [8,9]. Low solubility limits the application of natural RBP owing to the disulfide bonds and hydrophobic interactions in RBP, which control the spatial structure of protein $[10,11]$. Consequently, proper methods of modification are required to obtain suitable functional and structural protein properties.

Physical, chemical, and enzymatic modification are common modification methods used at present [12]. High hydrostatic pressure (HHP) processing is a new technology which could improve food quality and shelf life, and it may be a suitable processing method for the food industry [13-15]. As reports have shown, HHP treatment could change the 
tertiary and quaternary structures of proteins. This technology has already been applied to reduce or eliminate the allergenicity of protein, and improve the sensory and nutritional characteristics of food processing ingredients while inactivating microorganisms [16,17]. Some scholars have studied the functional and nutritional properties of soy protein isolate $[18,19]$ and RBP $[20]$ only processed by HHP treatment. Wang et al. [18] investigated the effects of 200-600 MPa high-pressure treatment on some physicochemical and functional properties of soy protein isolates at different concentrations. The study indicated that proper protein concentration and suitable HHP treatment could affect the emulsifying activity, solubility, and gelling property of soybean protein. Li et al. [19] studied the effects of HHP on the functional and nutritional characteristics of soy protein isolate in infant formula. The paper found that soy protein treated by HHP also showed better in vitro digestibility. Zhu et al. [20] reported that HHP treatment under 100-500 MPa pressure could modify functional properties such as gelling property, emulsifying property, emulsion stability etc. of RBP. This research also showed the relationship between surface hydrophobicity and the functional properties. Enzymatic modification is well known as a safe modification method to expose and release bioactive peptides without leading to protein nutrient loss [21]. Many scholars have carried out research into enzymatic protein modification, such as using rice bran, whey, corn, etc. as raw materials. Through enzymatic protein modification, the emulsification, freeze-thaw stability and oxidation resistance of protein have been improved [22-26]. HHP treatment is applied not only in novel food research but also in combination with enzymatic hydrolysis treatment to improve the functional properties of proteins [9]. Some scholars have reported the protease hydrolysis of soy protein isolate and lentil protein during HHP treatment $[9,27]$. Other investigators have studied the hydrolysis of soybean whey protein and ginkgo seed protein after HHP pretreatment $[28,29]$. Literature about the effects of HHP pretreatment on the structural and functional properties of rice bran protein hydrolysates (RBPH) have largely been unexplored.

The objective of the current work was to investigate the influence of HHP pretreatment on the structural and functional properties of RBPH, including its solubility, emulsifying activity index (EAI), emulsifying stability index (ESI), foaming capacity (FC), and foaming stability (FS). Besides, the mechanism of HHP pretreatment on RBPH was studied by observing the particle size and $\zeta$-potential, sodium dodecyl sulfate-polyacrylamide gel electrophoresis (SDS-PAGE), scanning electron microscopy (SEM), high-performance size exclusion chromatography (HPSEC) and Fourier transform infrared (FTIR) spectrum. The study will provide a basis for further elucidating the mechanisms of the functional properties of RBP modified by HHP pretreatment.

\section{Materials and Methods}

\subsection{Materials}

Fresh rice bran was purchased from Heilongjiang Great Northern Wilderness Agribusiness Group Co., Ltd. (Harbin, Heilongjiang, China). RBP was obtained in laboratory condition. Trypsin $\left(3 \times 10^{4} \mathrm{U} / \mathrm{g}\right)$ was obtained from Sigma-Aldrich Co. (St. Louis, MO, USA). Deionized water was used. Chemicals and reagents were of analytical grade.

\subsection{Extraction of RBP}

RBP was extracted in the laboratory according to Zang et al. [24]. Rice bran was defatted for $4 \mathrm{~h}$ with 10 volumes of N-hexane by magnetic stirring. The defatted rice bran was air-dried for $24 \mathrm{~h}$ at $25^{\circ} \mathrm{C}$. Tenfold deionized water was added to the defatted rice bran by stirring for $1 \mathrm{~h}$, then the $\mathrm{pH}$ of the solution was adjusted to 9.0 with $2 \mathrm{M} \mathrm{NaOH}$. After being stirred for $2 \mathrm{~h}$, the resulting suspension was centrifuged at $8000 \times g$ for $20 \mathrm{~min}$ at $4{ }^{\circ} \mathrm{C}$. The $\mathrm{pH}$ of the supernatant was adjusted to 4.5 with $2 \mathrm{M} \mathrm{HCl}$. The precipitated protein was obtained by centrifugation at $4000 \times g$ for $20 \mathrm{~min}$ at $4{ }^{\circ} \mathrm{C}$. The protein was dispersed in fivefold deionized water and washed twice. After centrifugation at $6000 \times \mathrm{g}$ for $10 \mathrm{~min}$, the $\mathrm{pH}$ was adjusted to 7.0 with $2 \mathrm{M} \mathrm{NaOH}$. The neutral RBP solution was freeze-dried in a 
freeze drier and stored at $-20{ }^{\circ} \mathrm{C}$. The protein content of this RBP was $91.67 \%$, which was determined by the Kjeldahl method $(\mathrm{N} \% \times 5.95)$.

\subsection{HHP Pretreatment}

HHP pretreatment was carried out at $25^{\circ} \mathrm{C}$ in HHP equipment (Ren-He Electromechanical Engineering CO., Shenyang, China), with water used as hydrostatic fluid. RBP was dispersed in a $0.01 \mathrm{M}$ phosphate buffer $(1 \%, w / v)$. RBP solutions $(200 \mathrm{~mL}$ in each bag) were packed in polyethylene plastic bags, sealed after exhausting the air, placed in HHP equipment. Samples were treated by HHP at 100, 200, and $300 \mathrm{MPa}$ for $30 \mathrm{~min}$. The indicated pressure was reached in 1 to $2 \mathrm{~min}$; this pressure was kept for $30 \mathrm{~min}$ and released to normal pressure in 1 to $2 \mathrm{~min}$. Each HHP treatment was conducted three times.

\subsection{Preparation of $R B P H$}

The hydrolysis experiment was carried out after HHP treatment. Hydrolysis of RBP by trypsin was performed at atmospheric pressure $(0.1 \mathrm{MPa})$ for $60 \mathrm{~min}$ according to Zang et al. [24], with some modifications. The RBP only hydrolyzed was used as a control. After the $\mathrm{pH}$ and temperature adjustments $\left(\mathrm{pH}=8,37^{\circ} \mathrm{C}\right)$, trypsin was added (enzyme/substrate $=1 / 20(w / v)$ ). Hydrolysis was performed in triplicate, and the reaction was stopped by heating the hydrolysates for $10 \mathrm{~min}$ at $90^{\circ} \mathrm{C}$. Next, the $\mathrm{pH}$ of the solution was maintained at 7 with $0.5 \mathrm{M} \mathrm{NaOH}$, and the supernatant was obtained by centrifugation at $6000 \times g$ for $15 \mathrm{~min}$ at $4{ }^{\circ} \mathrm{C}$. The supernatant was then stored at $-20^{\circ} \mathrm{C}$ until analysis.

\subsection{Solubility}

Solubility was determined according to Zang et al. [24] with slight modifications. Briefly, the RBPH samples were diluted with a phosphate buffer (0.01 M, pH 7.0) to a protein concentration of $1 \%(w / v)$, and the $\mathrm{pH}$ was adjusted to 7.0 . The dispersion was then centrifuged at $10,000 \times g$ for $20 \mathrm{~min}$. The protein content in the supernatant was measured by Lowry's method using bovine serum albumin (BSA) as the standard. Equation (1) was used to calculate the solubility.

$$
\text { Protein solubility }(\%)=\frac{\text { Protein content in the supernatant }}{\text { Total protein content in the sample }} \times 100
$$

\subsection{Emulsifying Properties}

The procedures of $\mathrm{Li}$ et al. [30] were used to measure the emulsifying properties of RBPH. The RBPH samples were diluted with a phosphate buffer $(0.01 \mathrm{M}, \mathrm{pH} 7.0)$ to a protein concentration of $0.5 \%(w / v)$, then $0.5 \%(w / v)$ of an RBPH $(12 \mathrm{~mL})$ solution was mixed with soybean oil ( $4 \mathrm{~mL}$ ) to prepare the emulsion by homogenizing for $1 \mathrm{~min}$ at 10,000 rpm. Next, $50 \mu \mathrm{L}$ of the microemulsion was removed from the bottom of the emulsion and immediately diluted with $5 \mathrm{~mL}$ of $0.1 \%$ sodium dodecyl sulfate (SDS) solution and vortexed. After that, the absorbance of the mixtures was measured at $500 \mathrm{~nm}$ for $0 \mathrm{~min}$ and $10 \mathrm{~min} ; 0.5 \%(w / v)$ of the RBPH solution was used as a control. Equations (2) and (3) were used to calculate EAI and ESI, respectively:

$$
\begin{gathered}
\operatorname{EAI}\left(\mathrm{m}^{2} / \mathrm{g}\right)=\frac{2 \times 2.303 \times \mathrm{A}_{0} \times 100}{1000 \times 0.25 \times 1 \times 0.005} \\
\operatorname{ESI}(\mathrm{min})=\frac{\mathrm{A}_{0}}{\mathrm{~A}_{0}-\mathrm{A}_{10}} \times\left(\mathrm{T}_{10}-\mathrm{T}_{0}\right)
\end{gathered}
$$

where $\mathrm{A}_{0}$ and $\mathrm{A}_{10}$ are the absorbance determined at $0 \mathrm{~min}$ and $10 \mathrm{~min}$, respectively. $\mathrm{T}_{0}$ is $0 \mathrm{~min}$, and $\mathrm{T}_{10}$ is $10 \mathrm{~min}$.

\subsection{Foaming Properties}

FC and FS were measured by the method of Zhang et al. [31]. Briefly, the RBPH samples were diluted with a phosphate buffer $(0.01 \mathrm{M}, \mathrm{pH} 7.0)$ to a protein concentration of 
$1 \%(w / v)$, and then $20 \mathrm{~mL}$ of $1 \%(w / v)$ of the RBPH sample solution diluted with deionized water was homogenized at 10,000 rpm for $1 \mathrm{~min}$. The homogenized sample was left to stand for $30 \mathrm{~min}$ at room temperature to calculate the FS. FC and FS were calculated by Equations (4) and (5):

$$
\begin{aligned}
& \mathrm{FC}(\%)=\frac{\mathrm{V}_{2}-\mathrm{V}_{1}}{\mathrm{~V}_{1}} \times 100 \\
& \mathrm{FS}(\%)=\frac{\mathrm{V}_{3}-\mathrm{V}_{1}}{\mathrm{~V}_{2}} \times 100
\end{aligned}
$$

where $V_{1}(m L)$ is volume before whipping, $V_{2}(m L)$ is volume after whipping, $V_{3}(m L)$ is volume after standing.

\subsection{Particle Size}

The samples were diluted with a phosphate buffer $(0.01 \mathrm{M}, \mathrm{pH} 7.0)$ to a protein concentration of $1 \%(w / v)$. The particle size and polydispersity index (PDI) analyses were performed with a particle size distribution instrument (Nano ZS 90; Malvern Instrument Co., Ltd., Malvern, Worcestershire, UK). The particle size was characterized by the $\mathrm{d} 4,3$ (volume average particle size).

\section{9. ऊ-Potential Measurements}

The samples were diluted with a phosphate buffer $(0.01 \mathrm{M}, \mathrm{pH} 7.0)$ to a protein

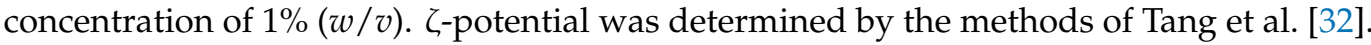
A Zetasizer Nano ZS 90 (Malvern Instrument Ltd., Malvern, Worcestershire, UK) was used to measure the $\zeta$-potential of RBPH.

\subsection{SDS-PAGE Analysis}

SDS-PAGE analysis was done by the method of Laemmli [33]. The RBPH samples was mixed with electrophoretic sample buffer $(10 \%$ glycerol, $0.5 \mathrm{M}$ Tris- $\mathrm{HCl}$ buffer, $5 \% \beta$ mercaptoethanol and 1\% bromophenol blue; $\mathrm{pH}$ 6.8) and boiled in boiling water for $5 \mathrm{~min}$. $6 \mu \mathrm{L}$ solution of each sample was loaded into proper well separately after cooling to room temperature. The stacking gel and the separating gel experiments were carried out at $90 \mathrm{~V}$ and $120 \mathrm{~V}$, respectively. The gels were stained by coomassie Brilliant Blue R-250.

\subsection{Free Sulfhydryl (SH) Content Determination}

SH content was determined by the method of Shimada \& Cheftel [34], with minor modifications. The RBPH solution of $1 \%(w / v)$ was solubilized in $5 \mathrm{~mL}$ of a Tris-Gly buffer solution (0.086 M Tris, $0.09 \mathrm{M}$ Gly, $0.004 \mathrm{M}$ EDTA and $8 \mathrm{M}$ urea; $\mathrm{pH}$ 8.0). This solution was added to a 2-nitrobenzoic acid (DTNB) $(20 \mu \mathrm{L})$ reagent. The absorbance of the mixture was measured at $412 \mathrm{~nm}$. The solution without DTNB was used as the blank.

The $-\mathrm{SH}$ content was calculated as Equation (6):

$$
-\mathrm{SH}(\mu \mathrm{mol} / \mathrm{g})=\frac{73.53 \times \mathrm{A}_{412} \times \mathrm{D}}{\mathrm{C}}
$$

where $\mathrm{A}_{412}$ was absorbance at $412 \mathrm{~nm}, \mathrm{C}$ was the solids content in protein solution $(\mathrm{mg} / \mathrm{mL})$, and $\mathrm{D}$ was the dilution factor.

\subsection{HPSEC Measurements}

HPSEC experiments were carried out using an Agilent 1100 liquid chromatograph equipped with a photodiode array detector according to Guan et al. [27], with some modifications. A $0.1 \%(w / v)$ protein concentration was obtained with a phosphate buffer (0.01 M, pH 7.0). A $0.45 \mu \mathrm{m}$ cellulose acetate membrane was used to remove impurities. The sample was injected onto a Shodex protein KW-804 column (Shodex Separation and HPLC Group, Tokyo, Japan), with a $0.01 \mathrm{M}$ phosphate buffer (pH 7.0) and $0.3 \mathrm{M} \mathrm{NaCl}$ used 
as the mobile phase. The flow rate was set at $1 \mathrm{~mL} / \mathrm{min}$. The eluent was monitored at $280 \mathrm{~nm}$.

\subsection{Surface Morphology Analysis}

The surface morphology of each sample was analyzed by Scanning electron microscopy (SEM, Hitachi SU8010, Tokyo, Japan). The samples were coated with Au using an ion sputter to a thickness of $15 \mathrm{~nm}$ and observed at an accelerating voltage of $5.0 \mathrm{kV}$.

\subsection{Fourier Transform Infrared (FTIR) Spectroscopy Measurements}

The structure of freeze-dried RBPH samples were measured by an FTIR spectrometer (PerkinElmer, Buckinghamshire, UK). The samples were pressed into pellets with $\mathrm{KBr}$ powder at a proportion of 1:100. The scanning range was set to $500-4000 \mathrm{~cm}^{-1}$ with a resolution of $4 \mathrm{~cm}^{-1}$ and 64 scans.

\subsection{Fluorescence Spectrometry Measurements}

Fluorescence spectrometry measurements were carried out by excitation at $290 \mathrm{~nm}$ by the method of Liu et al. [35] with slight modifications. The RBPH samples were diluted with a phosphate buffer $(0.01 \mathrm{M}, \mathrm{pH} 7.0)$ to a protein concentration of $1 \%(w / v)$. Emission wavelengths were collected between 300 and $450 \mathrm{~nm}$ with a constant slit of $2.5 \mathrm{~nm}$.

\subsection{Statistical Analysis}

Statistical comparisons were made at the significance level of $p<0.05$, and analysis of variance (ANOVA) and Duncan's test were used. All experiments were conducted in triplicate and SPSS 22.0 software was used to express the results as the mean values \pm standard deviations.

\section{Results and Discussion}

\subsection{Effect of HHP Pretreatment on the Solubility of RBPH}

Solubility is crucial for protein in food applications [36]. Figure 1 shows the effect of HHP pretreatment on the solubility of RBPH. Compared with the control group that was not pretreated by HHP, the solubility of RBPH increased significantly $(p<0.05)$. This may be the reason why the structure of the protein became loose through the HHP pretreatment, especially the exposure of hydrophilic and hydrophobic groups. Enzyme action sites in protein that are easily enzymatically digested were exposed, and the exposure of hydrophilic groups can make protein disperse or hydrate more readily [20]. HHP pretreatment leads to better hydrolysis of RBP. Thus, the solubility improved greatly. When the pressure increased, the solubility increased gradually until $200 \mathrm{MPa}$, and then decreased. The decrease in solubility through HHP pretreatment beyond $200 \mathrm{MPa}$ might be the reason for the buried hydrophobic groups being exposed when the protein was further unfolded [18].

\subsection{Effect of HHP Pretreatment on the Emulsifying Properties of RBPH}

The effects on the EAI and ESI of RBPH produced by HHP pretreatment are shown in Figure 2. Compared with the control group, EAI was significantly $(p<0.05)$ higher. When the pressure increased, EAI first increased and then decreased, and the maximal value was at $200 \mathrm{MPa}$. The present results share similarity to those of Wang et al. [18]. These results may be attributed to the unfolding of the RBP structure, which could increase RBP's sorption at the oil-water interface, hence increasing the EAI [20]. HHP pretreatment increased the ESI of RBPH as well. From 100 to $200 \mathrm{MPa}$, the ESI of samples pretreated by HHP increased significantly $(p<0.05)$ compared with the ESI of the control group, whereas ESI decreased slightly at $300 \mathrm{MPa}$. The balance between hydrophilicity and lipophilicity determines the emulsifying properties of proteins [37]. The structure of RBP unfolded after the HHP pretreatment, which favored enzymatic hydrolysis. This phenomenon facilitated interactions between the protein and solvents to prevent the accumulation of oil droplets. 
Molecular flexibility has been proven to be an essential requisite for the stability of an emulsion [38]. The decrease in ESI at $300 \mathrm{MPa}$ may be the reason why the molecular flexibility decreased under high pressure.

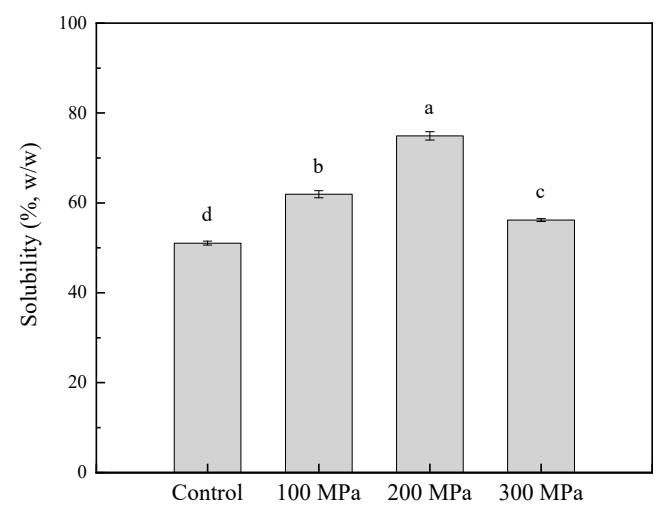

Figure 1. Effect of HHP pretreatment on the solubility of RBPH. HHP: high hydrostatic pressure; RBPH: rice bran protein hydrolysates. Control, $100 \mathrm{MPa}, 200 \mathrm{MPa}$, and $300 \mathrm{MPa}$ represent the RBPH samples subjected to 0,100, 200, and $300 \mathrm{MPa}$ pretreatment, respectively. Different lowercase letters indicate values that differ significantly $(p<0.05)$. All the HHP pretreatments were conducted at $25^{\circ} \mathrm{C}$ for $30 \mathrm{~min}$.

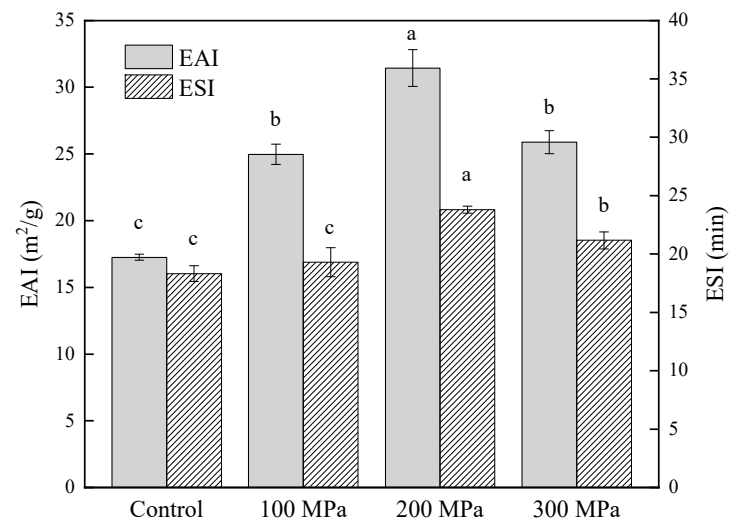

Figure 2. Effect of HHP pretreatment on the EAI and ESI of RBPH. HHP: high hydrostatic pressure; RBPH: rice bran protein hydrolysates; EAI: emulsifying activity index; ESI: emulsifying stability index. Control, $100 \mathrm{MPa}, 200 \mathrm{MPa}$, and $300 \mathrm{MPa}$ represent RBPH samples subjected to 0, 100, 200, and $300 \mathrm{MPa}$ pretreatment, respectively. Different lowercase letters indicate values that differ significantly $(p<0.05)$. All the HHP pretreatments were conducted at $25^{\circ} \mathrm{C}$ for $30 \mathrm{~min}$.

\subsection{Effect of HHP Pretreatment on the Foaming Properties of RBPH}

The FC and FS of RBPH pretreated by HHP are shown in Figure 3. The FC of HHPpretreated RBPH showed a trend of first increasing and then decreasing with the increase in pressure, and the HHP pretreatment at $200 \mathrm{MPa}$ produced the highest FC $(p<0.05)$. This trend is in parallel to the results of Maria et al. [39].

Compared with the control group, the FC of RBPH increased because of the HHP pretreatment, which increased the solubility of RBPH, unfolded part of the RBP structure, exposed buried hydrophobic groups, and increased the molecules' flexibility, consequently promoting protein adsorption in the foaming process and reducing interfacial tension between air and water. Li et al. [19] stated that partially unfolded protein tended to form high viscoelastic and mechanical networks by means of a noncovalent interaction. The protein achieved good FC and FS, as the structure kept a suitable balance between flexibility and rigidity [40]. Therefore, the decrease in FC at $300 \mathrm{MPa}$ may have been caused by the RBP structure's rigidity and flexibility becoming unbalanced at this high level of pressure. 
The FS values at $100-300 \mathrm{MPa}$ were $94 \%, 87.7 \%$, and $88.7 \%$, respectively, whereas that of the control group was $91 \%$. The trend of these results was consistent with that of Zhu et al. [20].

In this study, the trend of the FC data was in accordance with the trends of solubility, EAI and ESI (Figures 1 and 2).

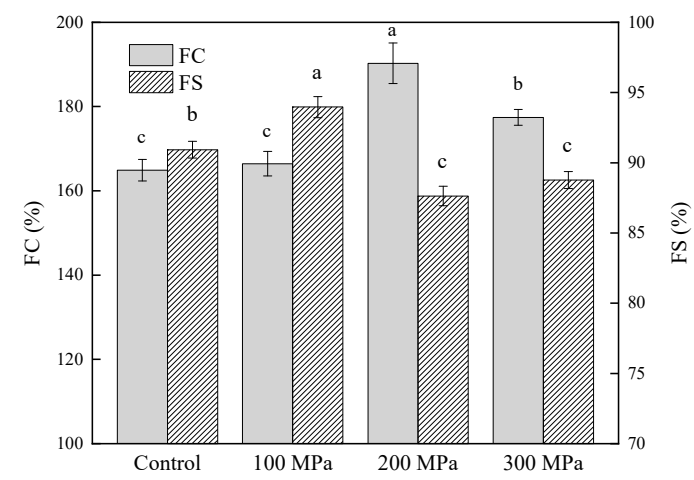

Figure 3. Effect of HHP pretreatment on the FC and FS of RBPH. HHP: high hydrostatic pressure; $\mathrm{RBPH}$ : rice bran protein hydrolysates; FC: foaming capacity; FS: foaming stability. Control, $100 \mathrm{MPa}$, $200 \mathrm{MPa}$, and $300 \mathrm{MPa}$ represent RBPH samples subjected to 0, 100, 200, and $300 \mathrm{MPa}$ pretreatment, respectively. Different lowercase letters indicate values that differ significantly $(p<0.05)$. All the $\mathrm{HHP}$ pretreatments were conducted at $25^{\circ} \mathrm{C}$ for $30 \mathrm{~min}$.

\subsection{Effect of HHP Pretreatment on the Particle Size of RBPH}

Figure 4 shows the volume average particle size $(\mathrm{d} 4,3)$ and the PDI of the control and samples pretreated by HHP. As shown in the figure, the mean particle size tended to be significantly smaller $(p<0.05)$ compared with the control. PDI also exhibited the same tendency as particle size. As reported, high pressure made the particle size smaller [41]. The trend of these results was in line with that of the solubility index (Figure 1).

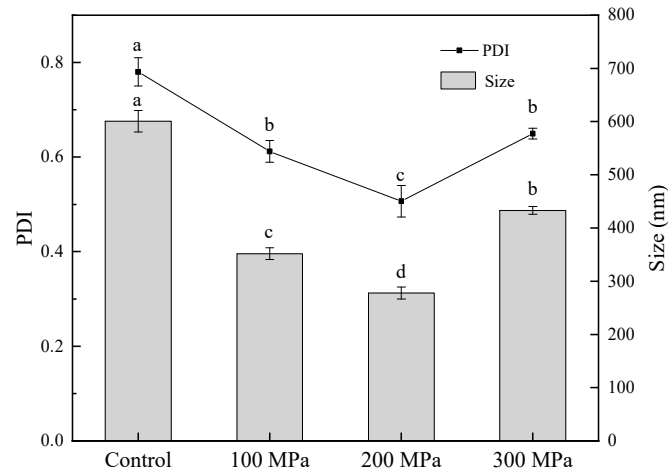

Figure 4. Effect of HHP pretreatment on the particle size and the PDI of RBPH. HHP: high hydrostatic pressure; RBPH: rice bran protein hydrolysates; PDI: polydispersity index; the particle size was characterized by the $\mathrm{d} 4,3$ (volume average particle size). Control, $100 \mathrm{MPa}, 200 \mathrm{MPa}$, and $300 \mathrm{MPa}$ represent RBPH samples subjected to 0, 100, 200, and $300 \mathrm{MPa}$ pretreatment, respectively. Different lowercase letters indicate values that differ significantly $(p<0.05)$. All the HHP pretreatments were conducted at $25^{\circ} \mathrm{C}$ for $30 \mathrm{~min}$.

The data showed the average particle size of the control group was the largest out of all four samples. With the increase in pressure, the mean particle size of RBPH first decreased to $278 \mathrm{~nm}$ at $200 \mathrm{MPa}$, then increased to $433 \mathrm{~nm}$ at $300 \mathrm{MPa}$. The PDI showed the same trend. This result may be caused by the three-dimensional structure of RBP molecules becoming loose through HHP, as the RBP molecules had a certain degree of dissociation and extension [20]. The protein was hydrolyzed to a smaller particle size easily by trypsin. When the pressure was too high (300 MPa), the RBPH molecules aggregated, which may 
have been caused by the balance changes in RBPH's spatial structure. Thus, the particle size became larger.

\subsection{Effect of HHP Pretreatment on the $\zeta$-Potential of RBPH}

The existence of protein on the surface of the droplet may generate an electric charge [42]. $\zeta$-potential can be used to determine the protein's surface charge density, which provides a sign of the potential stability of an emulsion liquid system [43]. Figure 5 shows significant $(p<0.05)$ changes in the $\zeta$-potential of the control and the RBPH samples pretreated by $\mathrm{HHP}$ of $-2.81 \mathrm{mV}$ (control group), $-5.1 \mathrm{mV}(100 \mathrm{MPa}),-3.68 \mathrm{mV}$ (200 MPa) and $-3.25 \mathrm{mV}$ $(300 \mathrm{MPa})$, respectively.

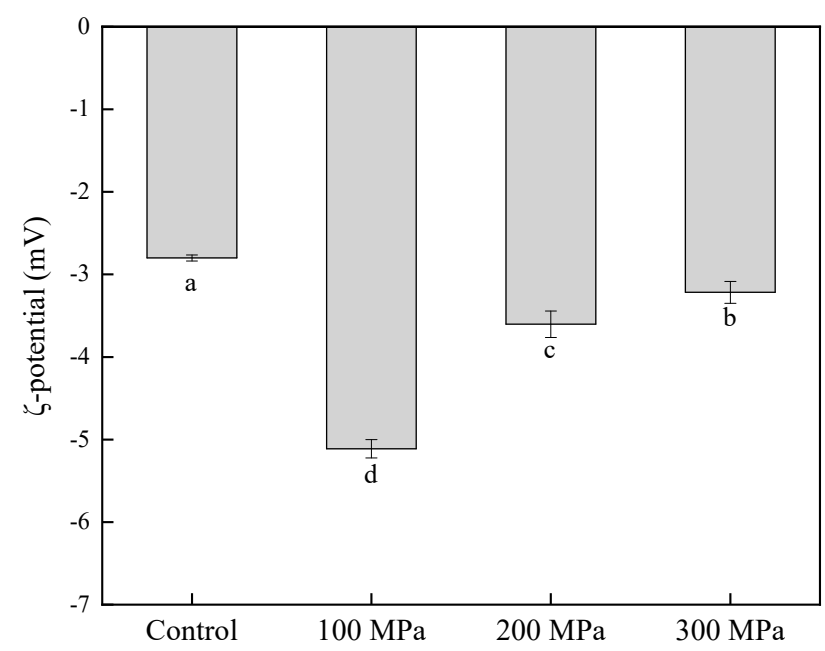

Figure 5. Effect of HHP pretreatment on the $\zeta$-potential of RBPH. HHP: high hydrostatic pressure; RBPH: rice bran protein hydrolysates. Control, $100 \mathrm{MPa}, 200 \mathrm{MPa}$, and $300 \mathrm{MPa}$ represent $\mathrm{RBPH}$ samples subjected to 0,100, 200, and $300 \mathrm{MPa}$ pretreatment, respectively. Different lowercase letters indicate values that differ significantly $(p<0.05)$. All the HHP pretreatments were conducted at $25^{\circ} \mathrm{C}$ for $30 \mathrm{~min}$.

Compared with the control group, the absolute value of RBPH's $\zeta$-potential in an aqueous dispersion was relatively larger. Theoretically, the absolute value of $\zeta$-potential is associated with the colloidal stability of protein dispersion. In general, the absolute value of $\zeta$-potential is positively correlated with intermolecular electrostatic repulsion. The greater the intermolecular repulsion, the better the stability of the colloid [44]. Therefore, RBPH pretreated by HHP had better colloidal stability. Compared with RBPH pretreated by $\mathrm{HHP}$ at $200 \mathrm{MPa}$ and $300 \mathrm{MPa}, \mathrm{RBPH}$ pretreated at $100 \mathrm{MPa}$ had a larger negative $\zeta$-potential in the dispersion and showed better colloidal stability. The result was not in parallel to the result of Li et al. [19], who concluded that HHP treatment could not affect the volume of soybean protein isolate significantly, which results in the non-obvious electrostatic interaction change. Our result was different. It was possible that the raw materials of protein and processing methods were different.

\subsection{Effect of HHP Pretreatment on SDS-PAGE Profiles of RBPH}

The electrophoretic bands of the control group and RBPH treated at 100-300 MPa are shown in Figure 6. RBPH showed four high density protein bands, which were distributed between $31.0 \mathrm{kDa}$ and $43.0 \mathrm{kDa}$, above $22.0 \mathrm{kDa}$, below $22.0 \mathrm{kDa}$, and below $14.4 \mathrm{kDa}$. This result was similar to the reports of Phongthai et al. [45] on RBPH's composition. Compared with the control group and pretreatment at $100 \mathrm{MPa}$, the large subunit components of RBPH after HHP pretreatment at $200 \mathrm{MPa}$ and $300 \mathrm{MPa}$ disappeared, and the content of the small subunit components increased significantly, indicating that more macromolecular protein components were hydrolyzed into smaller components. As shown by the data in 
Figures 1 and 4, the structure of RBP was unfolded after the HHP pretreatment (100 MPa, $200 \mathrm{MPa}$ ), which favored enzymatic hydrolysis. As the RBP molecules had a certain degree of dissociation and extension [20], RBP was easily hydrolyzed to a smaller particle size by trypsin. Thus, the solubility improved greatly. When the pressure was too high (300 MPa), the RBPH molecules aggregated, the particle size became larger, and the hidden hydrophobic groups were exposed [18]. The structural balance of the protein changed and its solubility decreased. However, the secondary bonds which caused protein molecule aggregation were destroyed under the SDS-PAGE conditions; thus, only the band below $14.4 \mathrm{kDa}$ was found at $300 \mathrm{MPa}$.

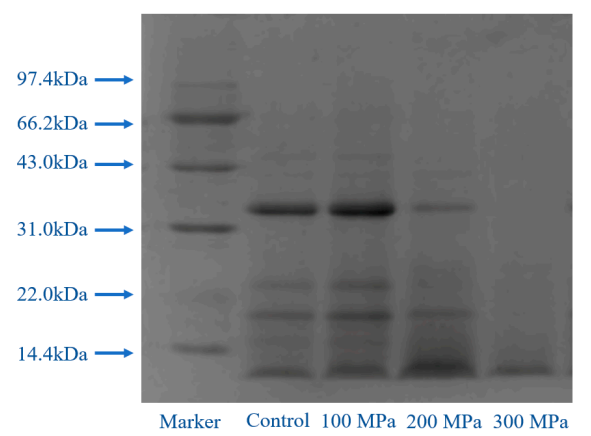

Figure 6. Effect of HHP pretreatment on the SDS-PAGE profiles of RBPH. HHP: high hydrostatic pressure; RBPH: rice bran protein hydrolysates; SDS-PAGE: sodium dodecyl sulfate-polyacrylamide gel electrophoresis. Control, $100 \mathrm{MPa}, 200 \mathrm{MPa}$, and $300 \mathrm{MPa}$ represent RBPH samples subjected to 0, 100, 200, and $300 \mathrm{MPa}$ pretreatment, respectively. All the HHP pretreatments were conducted at $25^{\circ} \mathrm{C}$ for $30 \mathrm{~min}$.

Current studies on protein hydrolysis have indicated that HHP treatment can destroy the disulfide bond of protein [46], and that enzymatic hydrolysis can break the peptide bond, which can transform the protein into smaller peptide fragments [47]. A report has also shown that the enzymatic hydrolysis of ginkgo seeds treated with HHP was better than that under atmospheric pressure [29].

As reported, a protein's structure can be changed by HHP, such as by unfolding, so that protease can enter the binding site for hydrolysis more effectively, increasing the sensitivity of protein to the enzyme [48]. With the increase in pressure, the bands of the RBPH subunits became lighter, which demonstrated that the RBPH structure had changed during the reaction. These findings are consistent with those of a previous study, which indicated that the structure of the protein changed after trypsin treatment [49]. Therefore, structure of RBPH pretreated by HHP was altered, resulting in changes in the functional properties.

\subsection{Effect of HHP Pretreatment on the Free SH Group Content of RBPH}

Free $\mathrm{SH}$ is a vital chemical bond that stabilizes the conformation of proteins [12]. It is usually used to characterize the changes in the structural and functional characteristics of proteins [50]. HHP pretreatment brought about some changes in SH content that appeared to be closely connected to protein unfolding.

Figure 7 shows that the $\mathrm{SH}$ content of RBPH samples was affected significantly by HHP pretreatment $(p<0.05)$; this result may be the reason why breaking of the noncovalent bonds induced unfolding of protein [51]. The SH content increased significantly $(p<0.05)$ at $100 \mathrm{MPa}$. However, when the pressure was higher than $100 \mathrm{MPa}$, the SH content of all $\mathrm{RBPH}$ samples gradually decreased as the pressure increased $(p<0.05)$. The result was similar to that of the SH content change trend found in a previous study [18]. The authors reported that HHP induced protein unfolding and subsequently aggregated the unfolded protein [18]. At $100 \mathrm{MPa}$, the free SH group may be stable, and the degree of aggregation was relatively low. However, under higher pressure, the protein disulfide bonds were 
re-formed prominently by a hydrophobic interaction which was caused by the aggregation of unfolded protein.

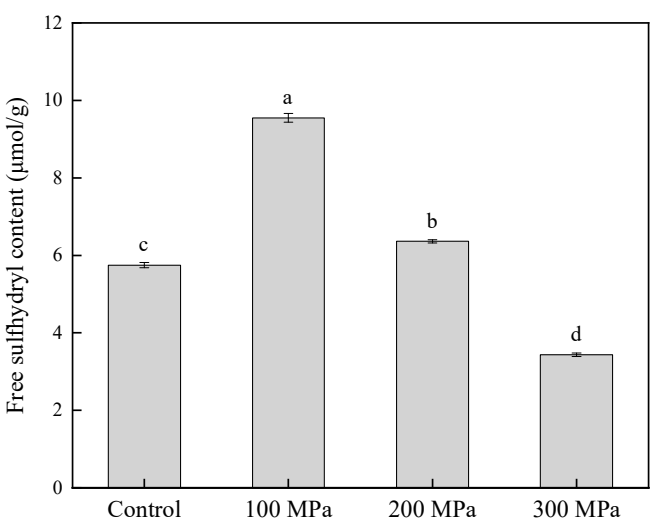

Figure 7. Effect of HHP pretreatment on the free sulfhydryl content of RBPH. HHP: high hydrostatic pressure; RBPH: rice bran protein hydrolysates. Control, $100 \mathrm{MPa}, 200 \mathrm{MPa}$, and $300 \mathrm{MPa}$ represent RBPH samples subjected to 0, 100, 200, and $300 \mathrm{MPa}$ pretreatment, respectively. Different letters indicate values that differ significantly $(p<0.05)$. All the HHP pretreatments were conducted at $25^{\circ} \mathrm{C}$ for $30 \mathrm{~min}$.

\subsection{Effect of HHP Pretreatment on the Molecular Weight Distribution of RBPH}

In this study, HPSEC was used to characterize the molecular weight distribution of RBPH pretreated by HHP. In the HPSEC profile of RBPH, there were four major elution peaks (Figure 8). These peaks were found at retention times of $<10 \mathrm{~min}, 10-11 \mathrm{~min}$, 11-12 $\mathrm{min}$, and >13 $\mathrm{min}$, which correspond to the molecular weight distribution above $27 \mathrm{kDa}, 22-27 \mathrm{kDa}, 18-22 \mathrm{kDa}$, and below $14 \mathrm{kDa}$, respectively (Table 1).

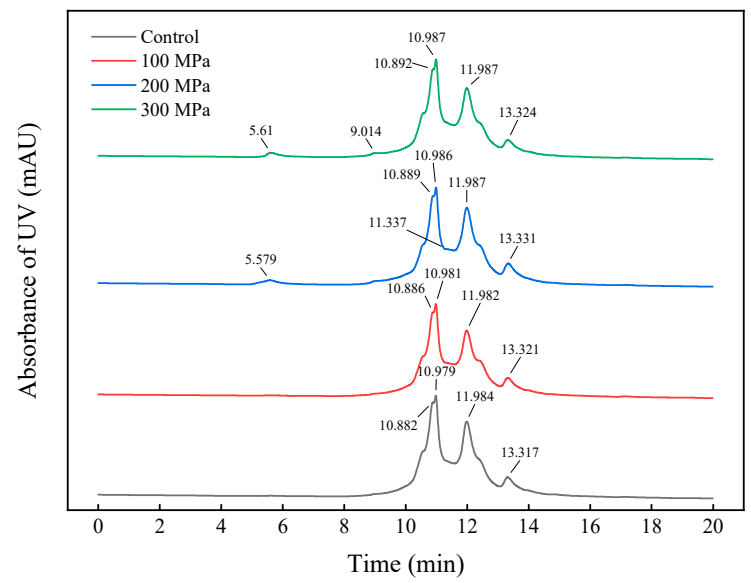

Figure 8. Effect of HHP pretreatment on the molecular-weight distribution profiles of RBPH. HHP: high hydrostatic pressure; RBPH: rice bran protein hydrolysates. Control, $100 \mathrm{MPa}, 200 \mathrm{MPa}$, and $300 \mathrm{MPa}$ represent RBPH samples subjected to 0, 100, 200, and $300 \mathrm{MPa}$ pretreatment, respectively. All the HHP pretreatments were conducted at $25^{\circ} \mathrm{C}$ for $30 \mathrm{~min}$.

With the increase in pressure, the amount of RBPH with a molecular weight of 22-27 kDa decreased gradually, while the proportions of RBPH with a weight of 18-22 kDa and below $14 \mathrm{kDa}$ increased. A small proportion of high-molecular-weight RBPH began to appear at $200 \mathrm{MPa}$. The amount of hydrolysate with a molecular weight above $27 \mathrm{kDa}$ was greatest at $300 \mathrm{MPa}$ out of all the samples. This phenomenon indicated that the hydrolysis and aggregation of protein occurred interactively. HHP pretreatment could unfold the protein structure to facilitate hydrolysis, and excessive pressure (300 MPa) pretreatment can 
lead to the aggregation of RBPH. This was the cause of the amount of low-molecular-weight $\mathrm{RBPH}(18-22 \mathrm{kDa},<14 \mathrm{kDa})$ reducing further at $300 \mathrm{MPa}$. The experiment data of this work (Figure 2) revealed that the emulsification of $\mathrm{RBPH}$ was optimal at $200 \mathrm{MPa}$, which indicated that peptide fragments of $18-22 \mathrm{kDa}$ were positively correlated with emulsification. This finding was in accordance with the particle size results of this experiment (Figure 4). Similarly, Guan et al. [27] reported that a combined treatment with HHP and enzymes can change the molecular weight distribution of proteins.

Table 1. Effect of HHP pretreatment on the molecular-weight distribution of RBPH.

\begin{tabular}{|c|c|c|c|c|}
\hline \multirow{3}{*}{ Samples } & \multicolumn{4}{|c|}{$\begin{array}{l}\text { Percentage Area of Peak (\%) Corresponding to Retention } \\
\text { Time/Molecular-Weight Distribution (min, kDa) }\end{array}$} \\
\hline & $<10 \mathrm{~min}$ & 10-11 min & $11-12 \mathrm{~min}$ & $>13 \mathrm{~min}$ \\
\hline & $>27 \mathrm{kDa}$ & 22-27 kDa & $18-22 \mathrm{kDa}$ & $<14 \mathrm{kDa}$ \\
\hline Control & n.d. & $51.66 \pm 0.01^{a}$ & $39.61 \pm 0.18^{b}$ & $8.73 \pm 0.17^{d}$ \\
\hline $100 \mathrm{MPa}$ & n.d. & $50.05 \pm 0.11^{c}$ & $39.65 \pm 0.04^{b}$ & $10.30 \pm 0.07^{a}$ \\
\hline $200 \mathrm{MPa}$ & $2.19 \pm 0.02^{b}$ & $38.90 \pm 0.11^{\mathrm{d}}$ & $48.84 \pm 0.06^{\mathrm{a}}$ & $10.07 \pm 0.03^{b}$ \\
\hline $300 \mathrm{MPa}$ & $2.52 \pm 0.01^{\mathrm{a}}$ & $50.98 \pm 0.12^{b}$ & $37.21 \pm 0.03^{c}$ & $9.29 \pm 0.08^{c}$ \\
\hline
\end{tabular}

Control, $100 \mathrm{MPa}, 200 \mathrm{MPa}$, and $300 \mathrm{MPa}$ represent RBPH samples subjected to 0, 100, 200, and $300 \mathrm{MPa}$ pretreatment, respectively. HHP: high hydrostatic pressure; RBPH: rice bran protein hydrolysates. The percentage area of peak represents the proportion of the integral of each peak area in the total integral of the peak areas. n.d., not detected. Different letters indicate values that differ significantly $(p<0.05)$. All the HHP pretreatments were conducted at $25^{\circ} \mathrm{C}$ for $30 \mathrm{~min}$.

\subsection{Effect of HHP Pretreatment on the Surface Morphology of RBPH}

The surface morphology of RBP and RBPH is exhibited in Figure 9. The RBP sample shows a larger sheet structure with irregular edges. The samples hydrolyzed by trypsin comprised smaller particles with smooth edges. The structure of RBP was unfolded after HHP pretreatment, and hydrolysis treatment led to further disruption of the spatial stereoscopic network structure of RBP. RBPH particles showed a smaller and more uniform size with smoother edges at $100 \mathrm{MPa}$ and $200 \mathrm{MPa}$. However, small particles decreased, and large particles increased when the HHP pretreatment was $300 \mathrm{MPa}$, which may be attributed to RBPH aggregation at higher pretreatment pressure. Generally, protein solubility can be affected by changes in particle size and structure [6]. The trend of the change in the morphology of RBPH was in accordance with the results seen for the solubility, emulsifying properties and particle size changes in this study (Figures 1, 2 and 4).
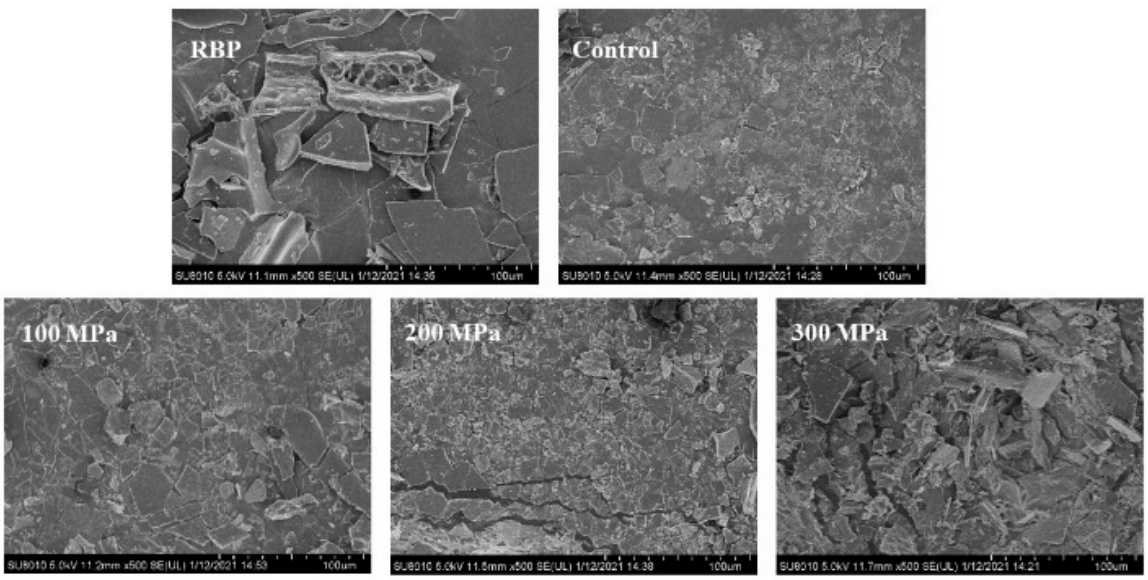

Figure 9. Effect of HHP pretreatment on the surface morphology of RBPH. HHP: high hydrostatic pressure; RBPH: rice bran protein hydrolysates; RBP: rice bran protein. Control, $100 \mathrm{MPa}, 200 \mathrm{MPa}$, and $300 \mathrm{MPa}$ represent RBPH samples subjected to 0, 100, 200, and $300 \mathrm{MPa}$ pretreatment, respectively. All the HHP pretreatments were conducted at $25^{\circ} \mathrm{C}$ for $30 \mathrm{~min}$. 


\subsection{Effect of HHP Pretreatment on the FTIR Spectra of RBPH}

In this experiment, the secondary structure of RBPH was studied using FTIR spectroscopy. As shown in Figure 10, the infrared spectrum was from $500 \mathrm{~cm}^{-1}$ to $4000 \mathrm{~cm}^{-1}$. Changes in a protein's secondary structure are generally evaluated by Amide I stretching (1700-1600 $\mathrm{cm}^{-1}, \mathrm{C}=\mathrm{O}$ of the peptide bond) and the Amide II shift $\left(1600-1500 \mathrm{~cm}^{-1}, \mathrm{~N}-\mathrm{H}\right.$ bending and $\mathrm{C}-\mathrm{N}$ stretching) [52-55]. It can be seen that some characteristic absorption peaks shifted after HHP pretreatment. The characteristic absorption peak of -OH stretching vibration in the control group was $3418 \mathrm{~cm}^{-1}$. When the pressure was $100 \mathrm{MPa}$, it shifted to $3409 \mathrm{~cm}^{-1}$. When the pressure increased, the characteristic peak continued to shift. The characteristic peak shifted to $3413 \mathrm{~cm}^{-1}$ at $300 \mathrm{MPa}$. The results showed that the characteristic absorption peak of -OH stretching vibration was a blue shift after HHP pretreatment, which may be due to the effect of the HHP pretreatment on the hydrogen bonds. The absorption peak at $2924 \mathrm{~cm}^{-1}$ represents the stretching vibration of $-\mathrm{CH}$. It shifted to $2926 \mathrm{~cm}^{-1}$ after HHP pretreatment. And the stretching vibration peak of $\mathrm{C}=\mathrm{O}$ shifted from $1654 \mathrm{~cm}^{-1}$ in the control group to $1667 \mathrm{~cm}^{-1}$ in the HHP pretreatment samples, and the characteristic peak of the stretching vibration of $\mathrm{C}-\mathrm{N}$ shifted from $1545 \mathrm{~cm}^{-1}$ to $1547 \mathrm{~cm}^{-1}$. Generally speaking, a protein's secondary structure is associated with the hydrogen bonds [56]. These results showed that, compared with the control group, RBPH's secondary structure changed from ordered to disordered, and the environment of the functional groups changed, indicating that the conformation of RBPH changed after HHP pretreatment.

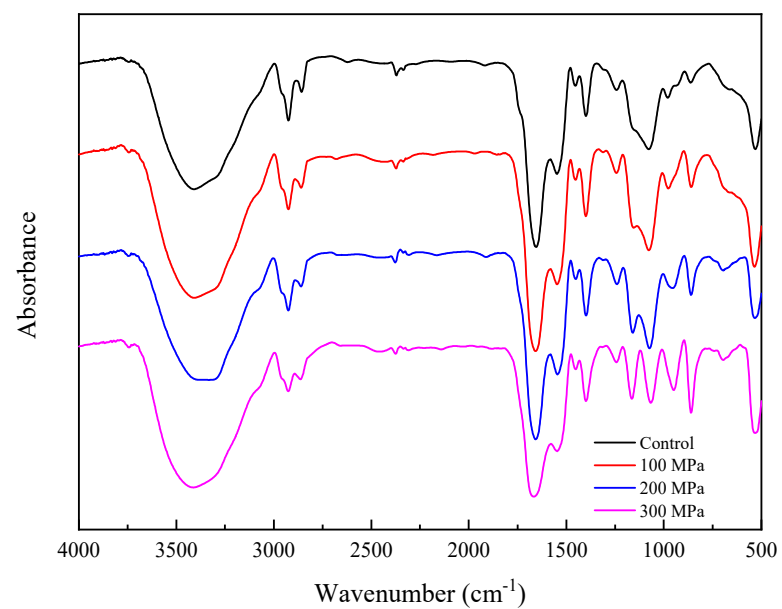

Figure 10. Effect of HHP pretreatment on the FTIR spectra of RBPH. HHP: high hydrostatic pressure; RBPH: rice bran protein hydrolysates; FTIR: Fourier transform infrared. Control, $100 \mathrm{MPa}, 200 \mathrm{MPa}$, and $300 \mathrm{MPa}$ represent RBPH samples subjected to 0, 100, 200, and $300 \mathrm{MPa}$ pretreatment, respectively. All the HHP pretreatments were conducted at $25^{\circ} \mathrm{C}$ for $30 \mathrm{~min}$.

\subsection{Effect of HHP Pretreatment on the Intrinsic Fluorescence Spectrum of RBPH}

Generally, the environmental polarity of tryptophan (Trp) affects the emission fluorescence spectra of protein. Trp is a sensitive means of characterizing the conformation of proteins and is considered as a measure for estimating the changes in a protein's tertiary structure [56]. A previous study had indicated that only when the maximum absorption wavelength $\left(\lambda_{\max }\right)$ and fluorescence intensity change at the same time can the spatial structure of protein be characterized [57].

The intrinsic fluorescence spectrum of RBPH is depicted in Figure 11. As shown in this figure, the maximum emission wavelength and fluorescence intensity of RBPH were affected by different HHP pretreatment conditions. This result indicates that the relative fluorescence intensity of RBPH increased when the pressure was $100 \mathrm{MPa}$ and $200 \mathrm{MPa}$, demonstrating that the hydrophobic groups were gradually exposed to the protein surface. With a further increase in pressure $(300 \mathrm{MPa})$, the fluorescence intensity decreased to a level 
even lower than that of the control group, which indicated that the exposed hydrophobic groups might have undergone recombination or aggregation, making the protein structure steady [18]. At the same time, it was found that the maximum emission wavelength underwent a redshift with an increase in pressure, which indicated that HHP pretreatment increased the polarity of the environment around Trp, which may be the reason why the protein structure unfolded and the contact between Trp and water increased. The maximum emission wavelength of RBPH in the control group was $346 \mathrm{~nm}$. The maximum emission wavelengths of RBPH treated with 100, 200, and $300 \mathrm{MPa}$ were $347 \mathrm{~nm}, 348 \mathrm{~nm}$, and $348 \mathrm{~nm}$, respectively. This result was consistent with that of a previous study which reported that $\mathrm{HHP}$ could increase the relative fluorescence intensity at a pressure of 100 to $200 \mathrm{MPa}$, whereas it decreased at 300 to $400 \mathrm{MPa}$ [20]. A fluorescence spectrum study confirmed that $\mathrm{RBPH}$ had undergone a conformational change through HHP pretreatment.

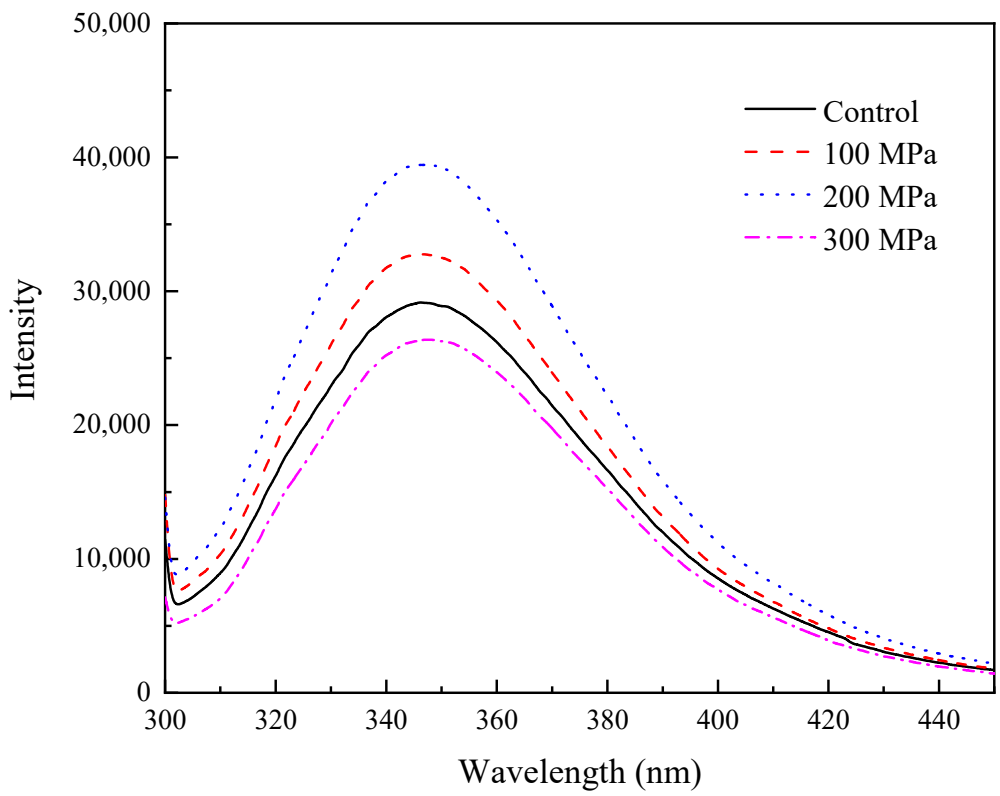

Figure 11. Effect of HHP pretreatment on the intrinsic fluorescence spectrum of RBPH. HHP: high hydrostatic pressure; RBPH: rice bran protein hydrolysates. Control, $100 \mathrm{MPa}, 200 \mathrm{MPa}$, and $300 \mathrm{MPa}$ represent RBPH samples subjected to 0,100, 200, and $300 \mathrm{MPa}$ pretreatment, respectively. All the $\mathrm{HHP}$ pretreatments were conducted at $25^{\circ} \mathrm{C}$ for $30 \mathrm{~min}$.

\section{Conclusions}

Overall, this work studied the structural and functional properties of RBPH pretreated by HHP. The current work indicated that RBPH exhibited significant improvements over the control in terms of the solubility, emulsifying properties, and foaming properties. The findings may indicate that HHP changed the spatial structure of RBP, thus enhancing the efficiency and effect of hydrolysis. The SDS-PAGE and free SH content results indicated that the primary structure of RBP altered after HHP pretreatment. The FTIR and fluorescence spectrum results showed that HHP changed the spatial structure of RBP. With the increase in pressure, the volume of the average particle size first decreased and then increased. The absolute value of the $\zeta$-potential of the HHP-pretreated RBPH in an aqueous dispersion was larger than that of the control. Thus, the data obtained from the experiment indicated that HHP pretreatment could effectively improve the functionality of RBPH. This processing technology could broaden the potential application of RBP in food products. Further studies should be implemented to investigate the proper hydrolysis degree of RBP achieved through HHP for application in various food products.

Author Contributions: Conceptualization, S.W. and G.Y.; Methodology and Software, S.W. and T.W.; Investigation, S.W. and Y.S.; Resources, L.J. and G.Y.; Formal analysis, T.W. and Y.C.; Writing-Original 
Draft Preparation, S.W.; Writing-Review \& Editing, G.Y. All authors have read and agreed to the published version of the manuscript.

Funding: This work was funded by the Major Science and Technology Projects in Heilongjiang Province (2021ZX12B02) and National Key Research and Development Program of China (2017YFD0401200).

Data Availability Statement: Not applicable.

Conflicts of Interest: The authors declare no conflict of interest.

\section{References}

1. Saji, N.; Francis, N.; Schwarz, L.J.; Blancchard, C.L.; Santhakumar, A.B. The antioxidant and anti-inflammatory properties of rice bran phenolic extracts. Foods 2020, 9, 829. [CrossRef]

2. Rafe, A.; Mousavi, S.S.; Shahidi, S.A. Dynamic rheological behavior of rice bran protein (rbp): Effects of concentration and temperature. J. Cereal. Sci. 2014, 60, 514-519. [CrossRef]

3. Han, S.W.; Chee, K.M.; Cho, S.J. Nutritional quality of rice bran protein in comparison to animal and vegetable protein. Food Chem. 2015, 172, 766-769. [CrossRef]

4. Shih, F.F.; Champagne, E.T.; Daigle, K. Use of enzymes in the processing of protein products from rice bran and rice flour. Mol. Nutr. Food Res. 1999, 43, 14-18. [CrossRef]

5. Saunders, R.M. The properties of rice bran as a foodstuff. Cereal. Food World 1990, 35, 632-636.

6. Ling, B.; Ouyang, S.; Wang, S. Effect of radio frequency treatment on functional, structural and thermal behaviors of protein isolates in rice bran. Food Chem. 2019, 289, 537-544. [CrossRef]

7. Hou, F.; Ding, W.; Qu, W.; Oladejo, A.O.; Xiong, F.; Zhang, W. Alkali solution extraction of rice residue protein isolates: Influence of alkali concentration on protein functional, structural properties and lysinoalanine formation. Food Chem. 2017, 218, 207-215. [CrossRef]

8. Schlegel, K.; Sontheimer, K.; Hickisch, A.; Wani, A.A.; Schweiggert-Weisz, U. Enzymatic hydrolysis of lupin protein isolateschanges in the molecular weight distribution, technofunctional characteristics, and sensory attributes. Food Sci. Nutr. 2019, 7, 2747-2759. [CrossRef]

9. Garcia-Mora, P.; Peñas, E.; Frias, J.; Gomez, R.; Martinez-Villaluenga, C. High-pressure improves enzymatic proteolysis and the release of peptides with angiotensin i converting enzyme inhibitory and antioxidant activities from lentil proteins. Food Chem. 2015, 171, 224-232. [CrossRef]

10. Wattanasiritham, L.; Theerakulkait, C.; Wickramasekara, S.; Maier, C.S.; Stevens, J.F. Isolation and identification of antioxidant peptides from enzymatically hydrolyzed rice bran protein. Food Chem. 2016, 192, 156-162. [CrossRef]

11. Wu, W.; Kong, X.; Zhang, C.; Hua, Y.; Chen, Y. Improving the stability of wheat gliadin nanoparticles-Effect of gum arabic addition. Food Hydrocolloid. 2018, 80, 78-87. [CrossRef]

12. Li, R.; Cui, Q.; Wang, G.; Liu, J.; Chen, S.; Wang, X. Relationship between surface functional properties and flexibility of soy protein isolate-glucose conjugates. Food Hydrocolloid. 2019, 95, 349-357. [CrossRef]

13. Rastogi, N.K.; Raghavarao, K.S.M.S.; Balasubramaniam, V.M.; Niranjan, K.; Knorr, D. Opportunities and challenges in high pressure processing of foods. Crit. Rev. Food Sci. 2007, 47, 69-112. [CrossRef]

14. Girgih, A.T.; Chao, D.; Lin, L.; He, R.; Jung, S.; Aluko, R.E. Enzymatic protein hydrolysates from high pressure-pretreated isolated pea proteins have better antioxidant properties than similar hydrolysates produced from heat pretreatment. Food Chem. 2015, 188, 510-516. [CrossRef]

15. Viacava, F.; Ramos-Parra, P.A.; Welti-Chanes, J.; Daniel, A.; Jacobo-Velázquez, D.A. High hydrostatic pressure processing of whole carrots: Effect of static and multi-pulsed mild intensity hydrostatic pressure treatments on bioactive compounds. Foods 2021, 10, 219. [CrossRef]

16. Peñas, E.; Prestamo, G.; Gomez, R. High pressure and the enzymatic hydrolysis of soybean whey proteins. Food Chem. 2004, 85, 641-648. [CrossRef]

17. Pereda, J.; Ferragut, V.; Buffa, M.; Guamis, B.; Trujillo, A.J. Proteolysis of ultra-high pressure homogenised treated milk during refrigerated storage. Food Chem. 2008, 111, 696-702. [CrossRef]

18. Wang, X.S.; Tang, C.H.; Li, B.S.; Yang, X.Q.; Li, L.; Ma, C.Y. Effects of high-pressure treatment on some physicochemical and functional properties of soy protein isolates. Food Hydrocolloid. 2008, 22, 560-567. [CrossRef]

19. Li, H.; Zhu, K.; Zhou, H.; Peng, W. Effects of high hydrostatic pressure on some functional and nutritional properties of soy protein isolate for infant formula. J. Agric. Food Chem. 2011, 59, 12028-12036. [CrossRef]

20. Zhu, S.M.; Lin, S.L.; Ramaswamy, H.S.; Yu, Y.; Zhang, Q.T. Enhancement of functional properties of rice bran proteins by high pressure treatment and their correlation with surface hydrophobicity. Food Bioprocess Technol. 2017, 10, 317-327. [CrossRef]

21. Phongthai, S.; D'Amico, S.; Schoenlechner, R.; Homthawornchoo, W.; Rawdkuen, S. Fractionation and antioxidant properties of rice bran protein hydrolysates stimulated by in vitro gastrointestinal digestion. Food Chem. 2018, 240, 156. [CrossRef] [PubMed]

22. Jin, D.X.; Liu, X.L.; Zheng, X.Q.; Wang, X.J.; He, J.F. Preparation of antioxidative corn protein hydrolysates, purification and evaluation of three novel corn antioxidant peptides. Food Chem. 2016, 204, 427-436. [CrossRef] 
23. Zang, X.; Yue, C.; Liu, M.; Zheng, H.; Xia, X.; Yu, G. Improvement of freeze-thaw stability of oil-in-water emulsions prepared with modified soy protein isolates. LWT-Food Sci. Technol. 2019, 102, 122-130. [CrossRef]

24. Zang, X.; Yue, C.; Wang, Y.; Shao, M.; Yu, G. Effect of limited enzymatic hydrolysis on the structure and emulsifying properties of rice bran protein. J. Cereal. Sci. 2019, 85, 168-174. [CrossRef]

25. Ewert, J.; Luz, A.; Volk, V.; Stressler, T.; Fischer, L. Enzymatic production of emulsifying whey protein hydrolysates without the need of heat inactivation. J. Sci. Food Agric. 2019, 99, 3443-3450. [CrossRef] [PubMed]

26. Zang, X.; Liu, P.; Chen, Y.; Wang, J.; Yu, G.; Xu, H. Improved freeze-thaw stability of o/w emulsions prepared with soybean protein isolate modified by papain and transglutaminase. LWT-Food Sci. Technol. 2019, 104, 195-201. [CrossRef]

27. Guan, H.; Diao, X.; Jiang, F.; Han, J.; Kong, B. The enzymatic hydrolysis of soy protein isolate by corolase pp under high hydrostatic pressure and its effect on bioactivity and characteristics of hydrolysates. Food Chem. 2018, 245, 89-96. [CrossRef] [PubMed]

28. Peñas, E.; Restani, P.; Ballabio, C.; Prestamo, G.; Fiocchi, A.; Gomez, R. Assessment of the residual immunoreactivity of soybean whey hydrolysates obtained by combined enzymatic proteolysis and high pressure. Eur. Food Res. Technol. 2006, 222, 286-290. [CrossRef]

29. Zhou, H.; Wang, C.; Ye, J.; Tao, R.; Chen, H.; Cao, F. Effects of enzymatic hydrolysis assisted by high hydrostatic pressure processing on the hydrolysis and allergenicity of proteins from ginkgo seeds. Food Bioprocess Technol. 2016, 9, 839-848. [CrossRef]

30. Li, C.; Huang, X.; Peng, Q.; Shan, Y.; Xue, F. Physicochemical properties of peanut protein isolate-glucomannan conjugates prepared by ultrasonic treatment. Ultrason. Sonochem. 2014, 21, 1722-1727. [CrossRef]

31. Zhang, H.J.; Zhang, H.; Wang, L.; Guo, X.N. Preparation and functional properties of rice bran proteins from heat-stabilized defatted rice bran. Food Res. Int. 2012, 47, 359-363. [CrossRef]

32. Tang, C.H.; Sun, X. A comparative study of physicochemical and conformational properties in three vicilins from phaseolus legumes: Implications for the structure-function relationship. Food Hydrocolloid. 2011, 25, 315-324. [CrossRef]

33. Laemmli, U.K. Cleavage of structural proteins during the assembly of the head of bacteriophage T4. Nature 1970, 227, 680-685. [CrossRef] [PubMed]

34. Shimada, K.; Cheftel, J.C. Determination of sulfhydryl groups and disulfide bonds in heat-induced gels of soy protein isolate. J. Agric. Food Chem. 1988, 36, 147-153. [CrossRef]

35. Liu, Y.; Zhao, G.; Zhao, M.; Ren, J.; Yang, B. Improvement of functional properties of peanut protein isolate by conjugation with dextran through maillard reaction. Food Chem. 2012, 131, 901-906. [CrossRef]

36. Bera, M.B.; Mukherjee, R.K. Solubility, emulsifying, and foaming properties of rice bran protein concentrates. J. Food Sci. 1989, 54, 142-145. [CrossRef]

37. Sathe, S.K.; Deshpande, S.S.; Salunkhe, D.K. Functional properties of lupin seed (lupinus mutabilis) proteins and protein concentrates. J. Food Sci. 1982, 47, 491-497. [CrossRef]

38. Kato, A.; Nakai, S. Hydrophobicity determined by a fluorescence probe method and its correlation with surface properties of proteins. BBA-Proteins Proteom. 1980, 624, 13-20. [CrossRef]

39. Maria, S.D.; Ferrari, G.; Maresca, P. Effects of high hydrostatic pressure on the conformational structure and the functional properties of bovine serum albumin. Innov. Food Sci. Emerg. 2015, 33, 67-75. [CrossRef]

40. Xu, S.; Damodaran, S. Comparative adsorption of native and denatured egg-white, human, and t4 phage lysozymes at the air-water interface. J. Colloid Interface Sci. 1993, 159, 124-133. [CrossRef]

41. Bouaouina, H.; Desrumaux, A.; Loisel, C.; Legrand, J. Functional properties of whey proteins as affected by dynamic high-pressure treatment. Int. Dairy J. 2006, 16, 275-284. [CrossRef]

42. Shanmugam, A.; Ashokkumar, M. Ultrasonic preparation of stable flax seed oil emulsions in dairy systems-physicochemical characterization. Food Hydrocolloid. 2014, 39, 151-162. [CrossRef]

43. Li, D.; Zhao, Y.; Wang, X.; Tang, H.; Wu, N.; Wu, F. Effects of (+)-catechin on a rice bran protein oil-in-water emulsion: Droplet size, zeta-potential, emulsifying properties, and rheological behavior. Food Hydrocolloid. 2020, 98, 105306. [CrossRef]

44. Achouri, A.; Boye, J.I.; Yaylayan, V.A.; Yeboah, F.K. Functional properties of glycated soy 11s glycinin. J. Food Sci. 2005, 70, C269-C274. [CrossRef]

45. Phongthai, S.; Lim, S.T.; Rawdkuen, S. Ultrasonic-assisted extraction of rice bran protein using response surface methodology. J. Food Biochem. 2017, 41, 19-23. [CrossRef]

46. Li, H.; Zhu, K.; Zhou, H.; Peng, W. Effects of high hydrostatic pressure treatment on allergenicity and structural properties of soybean protein isolate for infant formula. Food Chem. 2012, 132, 808-814. [CrossRef]

47. Toldrà, M.; Parés, D.; Saguer, E.; Carretero, C. Hemoglobin hydrolysates from porcine blood obtained through enzymatic hydrolysis assisted by high hydrostatic pressure processing. Innov. Food Sci. Emerg. 2011, 12, 435-442. [CrossRef]

48. Knudsen, J.C.; Otte, J.; Olsen, K.; Skibsted, L.H. Effect of high hydrostatic pressure on the conformation of $\beta$-lactoglobulin A as assessed by proteolytic peptide profiling. Int. Dairy J. 2002, 12, 791-803. [CrossRef]

49. Avramenko, N.A.; Low, N.H.; Nickerson, M.T. The effects of limited enzymatic hydrolysis on the physicochemical and emulsifying properties of a lentil protein isolate. Food Res. Int. 2013, 51, 162-169. [CrossRef]

50. Campbell, L.J.; Gu, X.; Dewar, S.J.; Euston, S.R. Effects of heat treatment and glucono- $\delta$-lactone-induced acidification on characteristics of soy protein isolate. Food Hydrocolloid. 2009, 23, 344-351. [CrossRef] 
51. Messens, W.; Van Camp, J.; Huyghebaert, A. The use of high-pressure to modify the functionality of food proteins. Trends Food Sci. Technol. 1997, 8, 107-112. [CrossRef]

52. Dzwolak, W.; Kato, M.; Taniguchi, Y. Fourier transform infrared spectroscopy in high-pressure studies on proteins. BBA-Proteins Proteom. 2002, 1595, 131-144. [CrossRef]

53. Yakimets, I.; Wellner, N.; Smith, A.C.; Wilson, R.H.; Farhat, I.; Mitchell, J. Mechanical properties with respect to water content of gelatin films in glassy state. Polymer 2005, 46, 12577-12585. [CrossRef]

54. Wu, H.; Wang, Q.; Ma, T.; Ren, J. Comparative studies on the functional properties of various protein concentrate preparations of peanut protein. Food Res. Int. 2009, 42, 343-348. [CrossRef]

55. Su, J.F.; Huang, Z.; Yuan, X.Y.; Wang, X.Y.; Li, M. Structure and properties of carboxymethyl cellulose/soy protein isolate blend edible films crosslinked by maillard reactions. Carbohyd. Polym. 2010, 79, 145-153. [CrossRef]

56. Han, Z.; Cai, M.J.; Cheng, J.H.; Sun, D.W. Effects of electric fields and electromagnetic wave on food protein structure and functionality: A review. Trends Food Sci. Technol. 2018, 75, 1-9. [CrossRef]

57. Shen, L.; Tang, C.H. Microfluidization as a potential technique to modify surface properties of soy protein isolate. Food Res. Int. 2012, 48, 108-118. [CrossRef] 